\title{
Komparasi Keaktifan Mahasiswa Dalam Pembelajaran Daring Dengan Pembelajaran Luring di STAI Darul Kamal NW Lombok Timur NTB
}

\author{
Lina Mardiana ${ }^{1}$, Rahmayatul Pani $^{2}$, Eli Ermawati ${ }^{3}$, Riskawati ${ }^{4}$ \\ 1ㅣamardianaro1o2@gmail.com, ${ }^{2}$ rahmayatul0602@gmail.com, ${ }^{3}$ e79983351@gmail.com, \\ 3riskawatisaupian20@gmail.com \\ 1, 2, 3,4 Manajemen Pendidikan Islam, STAI Darul Kamal, Lombok Timur, Indonesia.
}

\begin{abstract}
Abstrak
Model pembelajaran yang berbeda membuat suasana dalam proses pembelajran yang berbeda pula. Seperti halnya pembelajran daring dan pembelajran luring. Penelitian ini bertujuan untuk melihat komparasi keaktifan mahasiswa dalam pembelajaran daring dengan pembelajaran luring di STAI darul kamal NW kembang kerang Lombok Timur. Peneliti ingin mengetahui apakah model pembelajaran daring dan luring berdampak pada keaktifan mahasiswa dalam pembelajaran. Penelitian ini menggunakan metode kuantitatif dengan pendekatan komparatif yaitu membandingkan keaktifan mahasiswa pada saat daring dan luring. Keaktifan mahasiswa diukur menggunakan angket yang diberikan kepada 30 orang sampel penelitian. Pemilihan sampel dilakukan dengan perpousif random sampling dimana sampel yang dipilih adalah mahasiswa yang mengikuti perkulihan daring dan luring. Data hasil penelitian dianalisis dengan analisis uji komparasi atau uji t. Hasil analisis menunjukkan $p$ value uji $\mathrm{t}(0,000487418)$ lebih kecil dari taraf signifikansi $(0,05)$, dengan demikian $\mathrm{H}_{0}$ diterima. Ini berarti bahwa tidak ada perbedaan yang signifikan keaktifan mahasiswa dalam proses pembelajaran daring ataupun pembelajaran luring.
\end{abstract}

Kata-kata kunci : Pembelajran Darling, Pembelajran luring, keaktifan mahasiswa

\section{Pendahuluan}

Masa pandemi covid 19 semua aktivitas di instansi terhenti karena pemerintah mengkhawatirkan akan terjadinya penularan yang banyak kepada rakyat. Untuk itu pemerintah memberikan solusi pembelajaran dilakukan secara darring, dimana pada masa pandemi ini menyebabkan perubahan berbagai tatanan kehidupan tidak terkecuali dalam bidang pendidikan, pembelajaran di masa pandemi Covid-19, berdasarkan kebijakan pemerintah melalui Kementrian Pendidikan dan Kebudayaan, telah mengeluarkan Surat Edaran Kementerian Pendidikan dan Kebudayaan (Kemendikbud) No.4 Tahun 2020 tentang pelaksanaan kebijakan pendidikan dalam 
Jurnal manajemen dan budaya STAI Darul Kamal NW Kembang kerang

Volume 1 No 2 Tahun 2021

P-ISSN : 2775-1643

E-ISSN : 2774-6704

https://journal.staidk.ac.id/index.php/manajemenbudaya

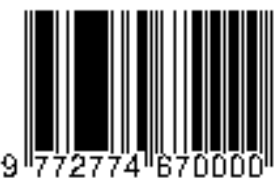

masa darurat penyebaran corona virus disease (Covid-19) yang terhitung mulai tanggal 24 Maret 2020. Dengan adanya kebijakan tersebut, seluruh instansi pendidikan segera merancang sistem pembelajaran yang di desain sedemikian rupa demi mencegah terjadinya penyebarluasan wabah Covid-19.

Berbagai desain pembelajaran baik daring dan luring telah banyak digunakan oleh sekolah-sekolah yang ada di Indonesia. Pembelajaran daring dapat di maknai sebagai suatu kegiatan belajar mengajar yang memanfaatkan jaringan atau koneksi internet sehingga terjalin komunikasi antara pendidik dan mahasiswanya tanpa melibatkan kontak fisik ${ }^{1}$. Pembelajaran menggunakan sistem daring tersebut tentunya memiliki berbagai kendala dalam pelaksanaannya. Pembelajaran daring mengharuskan guru, orang tua, maupun siswa mampu menggunakan internet.

Berbagai kendala yang sangat menghambat pelaksanaan pembelajaran daring di daerah pinggiran diantaranya adalah minimnya pengetahuan dan keterampilan menggunakan aplikasi yng disediakan untuk belajar, serta kemampuan menggunaan internet, koneksi jaringan yang buruk, dan kurangnya fasilitas pembelajaran daring seperti handphone, kuota internet. Permasalahan diatas, tentunya sangat menghambat pelaksanaan pembelajaran daring. Sehingga, pembelajaran kurang efektif. Terkendalanya pelaksanaan pembelajaran dan penilaian berpengaruh terhadap psikologi mahasiswa dan menurunya kualitas keterampilan². Oleh sebab itu, seluruh elemen pendidikan khususnya negara memiliki tanggung jawab dalam memfasilitasi terlaksananya pembelajaran jarak jauh untuk menekan kerugian dunia pendidikan dimasa yang akan datang.

Berdasarkan informasi yang diterima dari mahasiswa, belajar darimg kurang efektif karena kurangnya pemahaman yang diterima mahasiswa dalam proses belajar mengajar. Sekarang dimasa era new normal pemerintah memberikan instansi untuk belajar luring yaitu dengan cara tatap muka. Berdasarkan hasil pengamatan awal,

${ }^{1}$ Selvi Loviana and Waskita Niti Baskara, 'Dampak Pandemi Covid-19 Pada Kesiapan Pembelajaran Tadris Matematika Iain Metro Lampung', Journal Epsilon, 2.1 (2020), 62-70.

2 Rizqon Halal Syah Aji, 'Dampak Covid-19 Pada Pendidikan Di Indonesia: Sekolah, Keterampilan, Dan Proses Pembelajaran', SALAM: Jurnal Sosial Dan Budaya Syar-I, 7.5 (2020) $<$ https://doi.org/10.15408/sjsbs.v7i5.15314>. 
penulis melihat pembelajaran daring dimasa pandemi Covid-19 belum optimal. Terlihat kurangnya fasilitas yang mendukung pembelajaran daring seperti kurangnya pengetahuan dan keterampilan menggunakan internet serta aplikasi pembelajaran, tidak memiliki handphone android, paket internet, dan koneksi jaringan yang buruk yang menyebabkan mahasiswa kurang optimal dalam menerima pembelajaran,

Berdasarkan penjelasan diatas, penulis ingin mengetahui bagaimana komparatif keaktifan mahasiswa dalam pembelajaran daring dengan pembelajaran luring di STAI Darul Kamal NW Kembang Kerang Lombok Timur NTB di era new normal ini.

\section{Kajian pustaka}

Pembelajaran yang baik adalah pembelajaran yang dapat melibatkan peserta didik secara aktif mengikuti pembelajaran ${ }^{3}$. Keaktifan belajar peserta didik dapat terjadi apabila adanya faktor-faktor yang mendukung di dalamnya. Faktor-faktor belajar meliputi peserta didik, guru, materi, tempat, waktu, dan fasilitas ${ }^{4}$. Guru menjadi faktor yang paling berperan mewujudkan keaktifan peserta didik, karena gurulah yang berinteraksi lansung dengan peserta didik. Salah satu cara guru meningkatkan aktivitas belajar dan hasil belajar siswa adalah melalui model pembelajaran yang tepat. Diantara model pembelajaran yang dapat meningkatka keaktifan belajar adalah Examples Non Examples ${ }^{5}$, Model inkuiri', Model koperatif ${ }^{7}$ dan munkin model pembelajaran lainnya seperti model blended learning yang akan kita bahas dalam artikel ini.

${ }^{3}$ Feni Farida Payon, Dyka Andrian, and Sasi Mardikarini, 'Faktor Yang Mempengaruhi Keaktifan Belajar Peserta Didik Kelas III SD', Jurnal Ilmiah KONTEKSTUAL, 2021

${ }^{4}$ Nugroho Wibowo, 'Upaya Peningkatan Keaktifan Siswa Melalui Pembelajaran Berdasarkan Gaya Belajar Di Smk Negeri 1 Saptosari', Elinvo (Electronics, Informatics, and Vocational Education), 1.2 (2016).

5 Tazminar, 'Meningkatkan Keaktifan Belajar Dan Hasil Belajar Siswa Dengan Menggunakan Model Pembelajaran Examples Non Examples', Jupendas, 2015.

6 Ahmad Hariandi and Ayu Cahyani, 'Meningkatkan Keaktifan Belajar Siswa Menggunakan Pendekatan Inkuiri Di Sekolah Dasar', Jurnal Gentala Pendidikan Dasar, 2018

${ }^{7}$ Epriliana Rifanty, 'Peningkatan Keaktifan Belajar Menggunakan Model Pembelajaran Kooperatif Tipe Make a Match Pada Peserta Didik Kelas Vb Sd Muhammadiyah Condongcatur', JURNAL JPSD Vol.x No. x Tahun 20xx ISSN 2356-3869 (Print), 2614-0136 (Online), 2019. 
Jurnal manajemen dan budaya STAI Darul Kamal NW Kembang kerang

Volume 1 No 2 Tahun 2021

P-ISSN : 2775-1643

E-ISSN : 2774-6704

https://journal.staidk.ac.id/index.php/manajemenbudaya

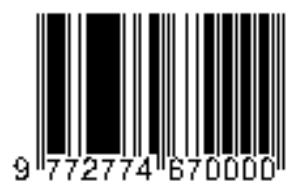

Istilah blended learning digunakan untuk menggambarkan solusi yang menggabungkan beberapa metode penyampaian yang berbeda ${ }^{8}$. Blended learning sedang marak digunakan dalam pembelajran, baik dikalangan akademis ataupun di perusahaan9. Terutama ketika pembatasan kegiatan pembelajaran karena covid-19, untuk mengurangi perkumpulan, pembelajaran disarankan menggunakan Blended learning yaitu campuran online dan offline, atau istilah yang sering digunakan daring dan luring.

\section{Pembelajaran daring dan pembelajaran luring}

KBBI Kemendikbud, daring adalah akronim dalam jaringan, terhubung melalui jejaring komputer, internet, dan sebagainya. Dilansir dari berbagai sumber, guru, dosen, siswa, dan mahasiswa kini melakukan kegiatan belajar-mengajar secara daring, termasuk pada saat pemberian tugas. Sedangkan luring Menurut KBBI Kemendikbud, luring adalah akronim dari luar jaring(an); terputus dari jejaring komputer. Misalnya, saat siswa dan mahasiswa belajar melalui buku pegangan siswa atau mahasiswa dan tenaga pengajar.

Daring adalah istilah yang sangat populer baru-baru ini. Istilah ini sering digunakan dalam sistem pembelajaran, yang dilakukan secara online atau menggunakan internet. Arti daring adalah akronim dari dalam jaringan, yang terhubung melalui jaringan komputer, internet dan lain sebagainya. Arti daring juga sering disamakan dengan suatu keadaan komputer yang dapat saling bertukar informasi, yang dihubungkan melalui internet. Selain daring, terdapat istilah luring yang juga dikenal sebagai penerapan sistem pembelajaran. Luring adalah akronim dari luar jaringan yang terputus dari jejaring komputer, atau bisa juga disebut dengan pembelajaran dalam sistem offline.

\section{Jenis Komunikasi Daring Berdasarkan Media}

8 Purnima Valiathan, 'Blended Learning Models', Astd, 2002, 2000-2003 $<$ https:// purnima-valiathan.com/wp-content/uploads/2015/09/Blended-Learning-Models2002-ASTD.pdf $>$.

9 Charles R Graham, 'Blended Learning Systems', Handbook of Blended Learning: Global Perspectives, Local Designs, 2006. 
Ada beberapa jenis komukasi daring berdasarkan media yang digunakan diantaranya:

1. Komunikasi Sinkron Video Call

Jenis komunikasi daring yang pertama adalah komunikasi sinkron video call. Komunikasi ini menggunakan cara video call, untuk menghubungkan satu sama lain dalam sistem pembelajaran online. Sehingga setiap individu akan tetap bertatap muka dalam layar telepon atau komputer.

2. Komunikasi Sinkron Chat

Jenis komunikasi yang kedua adalah komunikasi sinkron chat, yang dilakukan dalam bentuk obrolan tulisan dengan lawan bicara, seperti ini WhatsApp Chat, Line Chat, SMS atau Short Massage Service dan lain sebagainya.

3. Komunikasi Sinkron Call

Jenis komunikasi yang selanjutnya adalah komunikasi sinkron call, yang komunikasinya menggunakan cara bertelepon, atau berkomunikasi secara lisan menggunakan media telepon. Sehingga kamu tetap bisa berbicara dengan lawan bicaramu pada sebuah aplikasi yang ada di telepon.

4. Komunikasi Asinkron Video.

Jenis komunikasi asinkron video adalah berbagi rekaman video dengan lawan bicara. Sehingga kamu tidak bisa bicara secara langsung dengan lawan bicaramu, melainkan hanya saling berkirim video saja melalui sebuah aplikasi.

5. Komunikasi Asinkron Chat

Jenis komunikasi yang terakhir adalah komunikasi asinkron chat, yang dilakukan dengan komputer atau smartphone, yang terhubung melalui jaringan internet. Tetapi komunikasi yang digunakan tidak bisa secara langsung, tetapi menggunakan pesan yang terjalin secara tertunda.

\section{Kelebihan Komunikasi Daring :}

1. Lebih Cepat

Melalui komunikasi daring dapat memangkas waktu dan lebih cepat untuk bertukar informasi. Selain itu bisa lebih cepat dan efisien untuk menghubungi mitra 
bisnis atau kerabat. Karena dapat berkomunikasi dengan siapapun di seluruh dunia melalui email dan pesan teks secara instan. Internet juga telah menyediakan komunikasi tatap muka seperti Skype, media sosial, konferensi video, dan banyak cara lain yang ditawarkan oleh teknologi komunikasi online saat ini.

2. Menciptakan Lapangan Pekerjaan

Teknologi juga menciptakan lapangan pekerjaan baru bagi beberapa bidang seperti Analis sistem, pemrogram komputer, perancang web, pengembang perangkat keras dan perangkat lunak, dan banyak peluang baru lainnya yang diciptakan oleh teknologi komunikasi informasi (TIK). Teknologi komunikasi informasi (TIK) juga mempermudah bisnis untuk diotomatiskan sehingga pelanggan dapat menghubungi 24/7. Artinya, perusahaan dapat dibuka di mana saja, kapan saja, memungkinkan klien melakukan pembelian dari berbagai negara. Ini membuat bisnis lebih mudah dan nyaman.

3. Perbaikan Sektor Pendidikan

Internet telah menciptakan berbagai program komputer untuk digunakan dengan generasi yang berbeda di berbagai belahan dunia. Informasi penting seperti fakta kesehatan, bisnis, dan lingkungan dengan mudah tersedia dan dapat diakses oleh siapa saja dengan jaringan internet.

\section{Kelemahan Komunikasi Daring}

1. Kehilangan Data Pribadi

Meskipun internet telah membuat komunikasi menjadi lebih mudah, lebih cepat dan nyaman, masalah privasi telah muncul. Dari peretasan email hingga intersepsi sinyal telepon, semakin banyak orang sekarang bermasalah dengan informasi pribadi mereka. Pasalnya penggunaan media sosial atau menggunakan aplikasi berbasis teknologi harus memasukan data pribadi yang pastinya akan terbaca dan tersimpan oleh sistem mereka. Maka tidak heran banyak kasus kriminal seperti penipuan. Mengenai hal ini sebaiknya kita bisa lebih bijak menggunakan dan memberikan data pribadi kita. 
2. Berkurangnya Kesadaran Berbudaya

Meskipun internet telah menjadikan alam semesta sebagai desa global, beberapa budaya telah mengkonsumsi budaya lainnya. Namun mengakses internet berlebihan dapat menjadikan generasi muda tidak mengenal budaya asli mereka dan mengadopsi budaya dari luar. Hal ini sangat dapat berpengaruh dari cara mereka berpakaian, bertindak, dan berperilaku. Jadi meskipun kita harus beradaptasi dan bergerak dengan teknologi, ada hal-hal yang harus diperhatikan agar teknologi tidak menggerus budaya yang baik di sekitar kita.

3. Menyita Konsentrasi

Melaksanakan komunikasi daring tidak pada tempat dan waktu yang tepat, dapat mengabaikan atau menunda hal yang lain, bahkan membahayakan orang lain maupun diri sendiri. Maka dari itu perhatikan tempat dan waktu saat kita berkomunikasi secara daring.

\section{Metode}

Metode penelitian menggunakan komparatif kuantitatif, metode ini merupakan penelitian yang mempunyai sifat membandingkan. Penelitian komparatif digunakan untuk membandingkan persamaan serta perbedaan fakta dan sifat subjek penelitian berdasarkan kerangka pemikiran. Jadi, penelitian komparatif merupakan suatu jenis penelitian yang dilaksanakan untuk membandingkan antara beberapa kelompok terhadap suatu variabel tertentu. Populasi penelitian seluruh mahasiswa STAI Darul Kamal NW Kembang Kerang dengan mengambil sampel 30 orang mahasiswa. Teknik pengumpulan data dan instrumen data menggunakan angket, dengan analisis t-Test; two-sample Assuming Equal Variances.

\section{Pembahasan}

Pembelajaran daring dan luring muncul sebagai salah satu bentuk pola pembelajaran diera teknologi informasi seperti sekarang ini. Pembelajaran daring yang membutuhkan jaringan internet dan alat seperti HP androit, laptop dan lain-lain sedangkan pembelajaran luring tidak membutuhkan itu semuanya. Pembelajaran ini mulai terasa sangat dibutuhkan ketika masa pandemi covid 19 sehingga semua 
Jurnal manajemen dan budaya STAI Darul Kamal NW Kembang kerang

Volume 1 No 2 Tahun 2021

P-ISSN : 2775-1643

E-ISSN : 2774-6704

https://journal.staidk.ac.id/index.php/manajemenbudaya

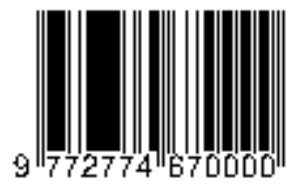

kampus menerapkan yang semula pembelajaran tatap muka berubah menjadi pembelajaran online termasuk kampus STAI Darul Kamal NW Kembang Kerang. Namun diera New Normal kampus diberikan kebijakan bahwa pemerintah membolehkan kampus melakukan tatap muka dan diselingi dengan pembelajaran online.

Proses pembelajaran daring dan luring yang ditawarkan oleh ahli pendidikan pasca pandemi covid 19. Walaupun demikian guru harus melakukan penyusaian dalam pembelajaran daring dan luring agar tercapainya tujuan dari materi pembelajaran yang diajarkan. Untuk mengukur perbandingan keaktifan mahasiswa STAI Darul Kamal NW Kembang Kerang dalam pembelajaran daring dan luring kami mendapatkan data dengan memberikan angket kepada mahasiswa STAI Darul Kamal NW Kembang Kerang.

Tabel 1. Hasil Uji t analisis keaktifan mahasiswa saat pembelajaran daring dan luring

\begin{tabular}{lrr}
\hline & Variable 1 & Variable 2 \\
\hline Mean & 3.333333333 & 4.633333333 \\
Variance & 1.954022989 & 1.757471264 \\
Observations & 30 & 30 \\
Pooled Variance & 1.855747126 & \\
Hypothesized Mean Difference & 0 & \\
Df & 58 & \\
t Stat & -3.695979753 & \\
P(T<=t) one-tail & 0.000243709 & \\
t Critical one-tail & 1.671552762 & \\
P(T<=t) two-tail & 0.000487418 & \\
t Critical two-tail & 2.001717484 & \\
\hline
\end{tabular}

Tabel diatas menunjukkan $P$ Value uji t sampel berpasangan (paried sampel) sebesar 0,000487418 lebih kecil dari nilai signifikansi $(0,05)$, maka tidak cukup alasan untuk menerima $\mathrm{H}_{1}$ sehingga $\mathrm{H}_{0}$ diterima. Berdasrkan hipotesis awal $\left(\mathrm{H}_{1}\right.$ : Ada 
perbedaan antara keaktifan mahasiswa dalam pembelajaran daring dan uring) dan Hipotesisi tandingan $\left(\mathrm{H}_{0}\right.$ : Tidak ada perbedaan yang signifikan keaktifan mahasiswa dalam pembelajaran daring dan luring) maka kesimpulan yang diperoleh adalah Tidak ada perbedaan yang signifikan keaktifan mahasiswa pada saat pembelajaran daring dan pada saat pembelajaran uring.

Pengukuran yang peneliti lakukan melihat beberapa indikator keaktifan mahasiswa diantaranya 1) kehadiran saat pembelajaran, 2) mengikuti instruksi yang diberikan dosen, 3) aktif bertanya, merespon dan menyampaikan pendapat, dan 4) fokus mengikuti pembelajaran. Diantara indikator tersebut hanya indikator ke-3 dan ke-4 yang menunjukan sedikit perbedaan. Mahasiswa lebih percaya diri bertanya, merespon dan menyampaikan pendapat pada saat pembelajran daring sehingga mereka lebih aktif. Sedangkan pada indikator ke-4 mahasiswa lebih fokus mengikuti pembelajaran saat luring daripada saat daring.

Secara umum ada beberapa perbedaan kondisi pembelajaran pada saat daring dan pembelajaran tatap muka. Pertama; dari segi Jarak dalam praktek dalam pembelajaran. Pada saat pembelajaran secara daring Tidak ada kebutuhan fisik seperti ruang kelas. Guru dan mahasiswa dipermudah karena bisa belajar dan mengajar dimana saja dan kapan saja meskipun dalam jarak yang jauh. Sedangkan ketika pembelejeeran secara tatap muka, proses pembelajaran membutuhkan ruang kelas secara fisik, guru dan mahasiswa harus bertemu, bertatap muka di waktu dan tempat secara bersama. Artinya jarak anatara guru dan mahasiswa begitu dekat sehingga komunikasi lebih intensif dan guru lebih mengontrol perkembagan pengrtahuan dan etika mahasiswa.

Kedua; dari segi waktu pembelajaran, ketika pembelajaran secara daring mahasiswa lebih lues dan dinamis mengatur waktu, mereka dapat belajar kapan saja tentu saja hal tersebut bisa menguntungkan bagi mahasiswa yang tidak memukinkan dan tidak banyak waktu untuk datang ke kelas secara fisik. Sedangkan pada saat pembelajaran secara tatap muka dibutuhkan waktu yang sama antara guru dan mahasiswa untuk bertemu dalam ruang kelas. Otomatis dibutuhkan kedisiplinan mengikuti pembelajaran di kelas. 
Ketiga; dari segi kemandirian dalam pembelajaran, pada saat pembelajaran secara daring mahasiswa dimudahkan dengan koneksi internet untuk belajar secara mandiri. Mahasiswa dapat mencari sendiri materi pembelajaran dari sumber lain sebagai referensi tembahan. Sedangkan ketika pembelajaran tatap muka, kemandirian belajar mahasiswa lebih dibatasi, pembelajaran difokuskan pada materi yang disampaikan oleh dosen atau pemakalah didepan kelas.

Keempat; dari segi kefokusan dalam mengikuti pembelajaran, ketika pembelajaran secara daring sering kali mahasiswa diberikan tugas lewat hand phone dalam aplikasi media kebanyakan tidak fokus mengikuti pembelajaran, disaat bersamaan melakukan aktivitas lain yang tidak berkaitan dengan pembelajaran, seperti chatting, ngobrol dengan yang lain, makan atau kegiatan lainnya. Sedangkan disaat pembelajaran secara tatap muka, mahasiswa fokus mengikuti pembelajaran yang berlansung karena di dampingi dosen dan mengerjakannya tanpa gangguan alat komunikasi lainnya. Juga aturan standar di kelas membantu mahasiswa fokus pembelajaran.

\section{Kesimpulan}

Hasil analisis menunjukkan $p$ value uji t $(0,000487418)$ lebih kecil dari taraf signifikansi $(0,05)$, maka tidak cukup alasan untuk menerima $\mathrm{H}_{1}$ sehingga $\mathrm{H}_{0}$ diterima. Berdasrkan hipotesis awal $\left(\mathrm{H}_{1}\right.$ : Ada perbedaan antara keaktifan mahasiswa dalam pembelajaran daring dan uring) dan Hipotesisi tandingan $\left(\mathrm{H}_{0}\right.$ : Tidak ada perbedaan yang signifikan keaktifan mahasiswa dalam pembelajaran daring dan luring) maka kesimpulan yang diperoleh adalah Tidak ada perbedaan yang signifikan keaktifan mahasiswa pada saat pembelajaran daring dan pada saat pembelajaran uring.

Diantara beberapa indikator keaktifan tersebut hanya indikator ke-3 yaitu aktif bertanya, merespon dan menyampaikan pendapat dan indikator ke-4 yaitu fokus mengikuti pembelajaran yang menunjukkan sedikit perbedaan. Mahasiswa lebih percaya diri bertanya, merespon dan menyampaikan pendapat pada saat pembelajran daring sehingga mereka lebih aktif. Sedangkan pada indikator ke-4 mahasiswa lebih fokus mengikuti pembelajaran saat luring daripada saat daring. 


\section{Daftar Pustaka}

Aji, Rizqon Halal Syah, 'Dampak Covid-19 Pada Pendidikan Di Indonesia: Sekolah, Keterampilan, Dan Proses Pembelajaran', SALAM: Jurnal Sosial Dan Budaya Syar-I, 7 (2020) <https:// doi.org/10.15408/sjsbs.v7i5.15314>

Farida Payon, Feni, Dyka Andrian, and Sasi Mardikarini, 'Faktor Yang Mempengaruhi Keaktifan Belajar Peserta Didik Kelas III SD', Jurnal Ilmiah KONTEKSTUAL, 2021 <https://doi.org/10.46772/kontekstual.v2i02.397>

Graham, Charles R, 'Blended Learning Systems', Handbook of Blended Learning: Global Perspectives, Local Designs, 2006

Hariandi, Ahmad, and Ayu Cahyani, 'Meningkatkan Keaktifan Belajar Siswa Menggunakan Pendekatan Inkuiri Di Sekolah Dasar', Jurnal Gentala Pendidikan Dasar, 2018 <https://doi.org/10.22437/gentala.v3i2.6751>

Loviana, Selvi, and Waskita Niti Baskara, 'Dampak Pandemi Covid-19 Pada Kesiapan Pembelajaran Tadris Matematika Iain Metro Lampung', Journal Epsilon, 2 (2020), 62-70

Rifanty, Epriliana, ‘Peningkatan Keaktifan Belajar Menggunakan Model Pembelajaran Kooperatif Tipe Make a Match Pada Peserta Didik Kelas Vb Sd Muhammadiyah Condongcatur', JURNAL JPSD Vol.x No. x Tahun 20xx ISSN 2356-3869 (Print), 2614-0136 (Online), 2019

Tazminar, 'Meningkatkan Keaktifan Belajar Dan Hasil Belajar Siswa Dengan Menggunakan Model Pembelajaran Examples Non Examples', Jupendas, 2015

Valiathan, Purnima, 'Blended Learning Models', Astd, 2002, 2000-2003 $<$ https:// purnima-valiathan.com/wp-content/uploads/2015/09/BlendedLearning-Models-2002-ASTD.pdf>

Wibowo, Nugroho, 'Upaya Peningkatan Keaktifan Siswa Melalui Pembelajaran Berdasarkan Gaya Belajar Di Smk Negeri 1 Saptosari', Elinvo (Electronics, Informatics, and Vocational Education), 1 (2016), 128-39 <https://doi.org/10.21831/elinvo.v1i2.10621> 